\title{
Trends in the Pattern of Facial Fractures in Different Countries of the World
}

\author{
Tendencias en el Patrón de Fracturas Faciales en Diferentes Países del Mundo \\ "Mohammad Shayyab; **Firas Alsoleihat; "Sukaina Ryalat \& ${ }^{* *}$ Ameen Khraisat
}

SHAYYAB, M.; ALSOLEIHAT, F.; RYALAT, S. \& KHRAISAT, A. Trends in the pattern of facial fractures in different countries of the world. Int. J. Morphol., 30(2):745-756, 2012.

SUMMARY: The aim of the present study was to examine the changes in the pattern of maxillofacial fractures between developed and developing countries over two time periods; (1987-1999) and (2000-2007). A comprehensive search of the literature using PubMed was conducted for publications on maxillofacial injuries published during the last 20 years. Only 45 articles met the inclusion criteria and the full-texts of these articles were thoroughly examined. For each of the included studies, different parameters were recorded. Calculated "weighed" percentages of each parameter across the total number of all patients were performed. The mandible was the most frequently fractured facial bone (57\%). In the total period, the mean age of patients with facial fractures was 24.4 years and the incidence of facial fractures was higher in males $(81.3 \%)$ than in females. The male to female ratio of patients with facial fractures was greater in developing countries (5.1:1.0) than that in developed countries (3.7:1.0) in the total period. Road traffic accident-related injuries had significantly decreased in developed countries and increased in developing countries over the two periods. However, assault-related facial injuries had significantly increased in developed countries and decreased in developing countries over the two periods. The body of the mandible was the most common mandibular fracture site (27.2\%). It was concluded that mandibular fractures are more common than middle third injuries of the facial skeleton. Most patients affected by facial fractures in different countries were young adult males.

KEY WORDS: Epidemiology; Maxillofacial fracture; Mandibular fracture; Road traffic accident.

\section{INTRODUCTION}

Data concerning maxillofacial trauma are plentiful, however few contain meaningful information as local demographic and socioeconomic factors greatly influence the results of any study. Literature showed that mandibular fractures are more common than middle third injuries of the facial skeleton (Layton et al., 1994; van Beek \& Merkx, 1999; Iida et al., 2001; Olasoji et al., 2002; Motamedi, 2003; Adebayo et al., 2003; Al Ahmed et al., 2004; Ansari, 2004; Erol et al., 2004; Laski et al., 2004; Cheema \& Amin, 2006; Brasileiro \& Passeri, 2006; Kadkhodaie, 2006; Al-Khateeb \& Abdullah, 2007; Subhashraj et al., 2007) (Table I). For example, in Scotland and Greenland, mandibular fractures were reported in $84 \%$ and $65 \%$ of facial fractures, respectively (Lindqvist et al., 1986; Adi et al., 1990), however, it reached $97 \%$ out of 129 cases of facial trauma in an 18-month period study in Greenland (Thorn et al., 1986). This was lower in the United States of America (USA), where mandibular fractures were $51 \%$ of the reported facial fractures (Vetter et al., 1991). Earlier studies in European countries reported lower incidence of mandibular fractures (Van Hoof et al., 1977; Brook \& Wood, 1983). In other regions of the world, these types of fractures showed a relevant or higher incidence in Nigeria, Iraq, and Jordan (Abiose, 1986; Kummoona \& Muna, 2006; Oji, 1999; Le et al., 2001; Karyouti, 1987; Bataineh, 1998; Ma'aita, 1999).

Generally, the incidence of maxillofacial fractures was higher in males than in females (Table II). This was well illustrated by different reports from different countries (Mwaniki \& Guthua, 1990; Vetter et al.; Hill et al., 1998; Kruger et al., 2006; Fasola et al., 2003a; Bakardjiev \& Pechalova, 2007) with peak incidence between the ages of 20 to 30 years (Chambers \& Scully, 1987; Allan \& Daly, 1990; Adi et al.; Rix et al., 1991; Bataineh; Bochlogyros, 1998; Ma'aita; Oji; Brasileiro \& Passeri, 2006; Kadkhodaie, 2006) (Table II).

Many factors have been implicated in the aetiology of facial trauma. The causes of fracture of the facial skeleton vary from one study to another, but they are chiefly road

\footnotetext{
* Department of Oral and Maxillofacial Surgery, Oral Medicine and Periodontology, Faculty of Dentistry, University of Jordan, Amman, Jordan

**: Department of Conservative Dentistry and Prothodontics, Faculty of Dentistry, University of Jordan, Amman, Jordan
} 
Table I. Location of study, year of study, number of patients analyzed and number of patients with mandibular fractures in studies dealing with maxillofacial fractures.

\begin{tabular}{|c|c|c|c|c|c|c|}
\hline Author(s) & $\begin{array}{l}\text { Country of } \\
\text { Study }\end{array}$ & $\begin{array}{c}\text { Year of } \\
\text { Publication }\end{array}$ & $\begin{array}{l}\text { Unit } \\
\text { Type }\end{array}$ & $\begin{array}{l}\text { Target } \\
\text { Fractures }\end{array}$ & $\begin{array}{l}\mathrm{N}^{0} \text { of } \\
\text { Patients }\end{array}$ & $\begin{array}{l}\text { Mandible } \\
\text { ( } N^{\circ} \text { of Patients) }\end{array}$ \\
\hline Bakardjiev et al. & Bulgaria & 2007 & Hosp. & Maxfac. & 1706 & 1261 \\
\hline Al-Khateeb et al. & UAE & 2007 & Hosp. & Maxfac. & 288 & 203 \\
\hline Deogratius et al. & Tanzania & 2003 & Emerg & Maxfac. & 314 & 222 \\
\hline Brasileiro et al. & Brazil & 2006 & Emerg & Maxfac. & 1024 & 423 \\
\hline Kadkhodaie & Iran & 2006 & Hosp. & Maxfac. & 7200 & 3089 \\
\hline Cheema \& Amin & Pakistan & 2006 & Tert. & Maxfac. & 702 & 473 \\
\hline Erolet al. & Turkey & 2004 & Hosp. & Maxfac. & 2901 & 2111 \\
\hline Adebayo et al. & Nigeria & 2003 & Emerg & Maxfac. & 443 & 305 \\
\hline Motamedi & Iran & 2003 & Emerg & Maxfac. & 237 & 180 \\
\hline Subhashraj et al. & India & 2007 & Emerg & Maxfac. & 2748 & 1176 \\
\hline Al Ahmed et al. & UAE & 2004 & Hosp. & Maxfac. & 230 & 170 \\
\hline Ansari & Iran & 2004 & Emerg & Maxfac. & 2268 & 1194 \\
\hline Olasoji etal. & Nigeria & 2002 & Emerg & Maxfac. & 306 & 225 \\
\hline van B eek et al. & Netherlan-ds & 1999 & Emerg & Maxfac. & 1379 & 822 \\
\hline van B eek et al. & Netherlan-ds & 1999 & Emerg & Maxfac. & 1324 & 707 \\
\hline Ugboko et al. & Nigeria & 1998 & Tert. & Maxfac. & 442 & 288 \\
\hline Bataineh & Jordan & 1999 & Hosp. & Maxfac. & 563 & 419 \\
\hline Oji & Nigeria & 1999 & Tert. & Maxfac. & 900 & 661 \\
\hline Fasola et al. (2003b) & Nigeria & $2003 b$ & Tert. & Maxfac. & 341 & 348 \\
\hline Fasola et al. (2003b) & Nigeria & $2003 b$ & Tert. & Maxfac. & 483 & 362 \\
\hline Aksoy et al. & Turkey & 2002 & Hosp. & Maxfac. & 553 & 417 \\
\hline Iida et al. & Japan & 2001 & Emerg & Maxfac. & 1502 & 955 \\
\hline Klenk et al. & UAE & 2003 & Hosp. & Maxfac. & 144 & 97 \\
\hline Sakretal. & Egypt & 2006 & Hosp. & Mand. & 509 & \#\# \\
\hline Ortako_luet al. & Turkey & 2002 & Hosp. & Maxfac. & 157 & 120 \\
\hline King et al. & USA & 2004 & Tert. & Mand. & 134 & \#\# \\
\hline Atanasov & Bulgaria & 2003 & Hosp. & Mand. & 2252 & \#\# \\
\hline Dongas & Australia & 2002 & Hosp. & Mand. & 251 & \#\# \\
\hline Schön et al. & Australia & 2001 & Hosp. & Maxfac. & 203 & 114 \\
\hline Mohammadi et al. & Aust ralia & 2007 & Hosp. & Maxfac. & 200 & 60 \\
\hline Allan et al. & Australia & 1990 & Hosp. & Mand. & 1162 & \#\# \\
\hline Khan & Zimbabwe & 1988 & Emerg & Maxfac. & 311 & 234 \\
\hline Layton et al. & UK & 1994 & Tert. & Maxfac. & 760 & 426 \\
\hline Dimitroulis et al. & $\mathrm{UK}$ & 1991 & Tert. & Maxfac. & 439 & 246 \\
\hline Perkins etal. & UK & 1988 & Tert. & Maxfac. & 360 & 202 \\
\hline Telfer et al. & $\mathrm{UK}$ & 1991 & Tert. & Maxfac. & 4305 & 2411 \\
\hline Adi etal. & Scotland (UK) & 1990 & Tert. & Maxfac. & 692 & 378 \\
\hline Vetter et al. & USA & 1991 & Tert. & Maxfac. & 311 & 157 \\
\hline Ashar etal. & UAE & 1996 & Hosp. & Maxfac. & 170 & 109 \\
\hline Sawhney et al. & India & 1988 & Emerg & Maxfac. & 262 & 123 \\
\hline Guven & Turkey & 1988 & Hosp. & Maxfac. & 190 & 139 \\
\hline Guven & Turkey & 1988 & Hosp. & Maxfac. & 212 & 154 \\
\hline Sugiura et al. & Japan & 1997 & Emerg & Maxfac. & 1170 & 646 \\
\hline Karyouti & Jordan & 1987 & Hosp. & Maxfac. & 131 & 70 \\
\hline Mwaniki et al. & Kenya & 1988 & Emerg & Mand. & 355 & \#\# \\
\hline
\end{tabular}

(\#\#: Not applicable; Hosp.: Hospital; Emerg.: Emergency; Tert.: Tertiary; Maxfac.: Maxillofacial; Mand.: Mandibular).

traffic accidents (RTA), interpersonal violence, falls, sports and industrial accidents (Table II).
Road traffic accidents have, in the past, been the most frequent cause of facial fractures in many countries including 
SHAYYAB, M.; ALSOLEIHAT, F.; RYALAT, S. \& KHRAISAT, A. Trends in the pattern of facial fractures in different countries of the world. Int. J. Morphol., 30(2):745-756, 2012.

Table II. Sex distribution, mean age and number of patients with facial fractures due to main aetiological factors.

\begin{tabular}{|c|c|c|c|c|}
\hline Author(s) & $\begin{array}{l}\text { Sex Distribution } \\
\text { ( } \mathbf{N}^{0} \text { of Males) }\end{array}$ & Mean Age & $\begin{array}{c}\text { RTA-Related } \\
\text { Injuries (N } \mathbf{N}^{\circ} \text { of } \\
\text { Patients) }\end{array}$ & $\begin{array}{c}\text { Assault-Related } \\
\text { Injuries ( } \mathbf{N}^{\circ} \text { of } \\
\text { Patients) }\end{array}$ \\
\hline Bakardjiev et al. & 1406 & 25.5 & 264 & 1040 \\
\hline Al-Khateeb \& Abdullah & 253 & 27.5 & 161 & 26 \\
\hline Deogratius etal. & 261 & 24.5 & 43 & 181 \\
\hline Brasi leiro et al. & 818 & 25.5 & 461 & 231 \\
\hline Kadkhodaie & 6646 & 24.5 & 6552 & 208 \\
\hline Cheema \& Amin & 596 & 25.5 & 382 & 56 \\
\hline Erolet al. & 2248 & 27.0 & 1104 & 299 \\
\hline Adebayo et al. & 363 & 30.0 & 246 & 50 \\
\hline Motamedi & 211 & 38.0 & 128 & 23 \\
\hline Subhashraj et al. & 2163 & 25.5 & 1710 & 93 \\
\hline Al Ahmed et al. & 212 & 24.5 & 174 & 18 \\
\hline Ansari & 1800 & 24.6 & 1360 & 227 \\
\hline Olasoji et al. & 210 & 29.0 & 111 & 147 \\
\hline van B eek et al. & 1033 & 28.4 & 940 & 104 \\
\hline van B eek et al. & 979 & 29.9 & 668 & 178 \\
\hline Ugboko et al. & 356 & 25.5 & 318 & 37 \\
\hline Bataineh & 424 & 28.8 & 311 & 95 \\
\hline Oji & 677 & 25.5 & 747 & 75 \\
\hline Fasola et al. (2003b) & 295 & 25.5 & 264 & 30 \\
\hline Fasola et al. (2003b) & 370 & 30.0 & 334 & 58 \\
\hline Aksoy et al. & 457 & 33.5 & 498 & 15 \\
\hline Iida et al. & 1110 & 19.5 & 787 & 233 \\
\hline Klenk et al. & 120 & 26.5 & 85 & 6 \\
\hline Sakr et al. & 400 & 25.0 & 198 & 83 \\
\hline Ortakoulu et al. & 151 & 22.8 & 69 & 42 \\
\hline King etal. & 120 & 30.0 & 39 & 67 \\
\hline Atanasov & 1876 & 24.5 & 452 & 1570 \\
\hline Dongas & 205 & 25.5 & 26 & 133 \\
\hline Schön etal. & 124 & 24.5 & 20 & 128 \\
\hline Mohammadi et al. & 178 & 27.5 & 84 & 72 \\
\hline Allan etal. & 947 & 24.5 & 250 & 443 \\
\hline Khan & 252 & 25.5 & 46 & 254 \\
\hline Layton et al. & 638 & 28.0 & 77 & 472 \\
\hline Dimitroulis et al. & 369 & 28.0 & 70 & 243 \\
\hline Perkins etal. & 294 & 28.0 & 68 & 136 \\
\hline Telfer et al. & 3616 & 28.0 & 745 & 2158 \\
\hline Adi etal. & 283 & 24.5 & 53 & 213 \\
\hline Vetter et al. & 230 & 29.7 & 124 & 115 \\
\hline Ashar etal. & 146 & 24.5 & 102 & 10 \\
\hline Sawhney et al. & 208 & 30.5 & 131 & 34 \\
\hline Guven & 149 & 25.5 & 91 & 56 \\
\hline Guven & 158 & 35.5 & 94 & 67 \\
\hline Sugiura et al. & 848 & 19.5 & 646 & 184 \\
\hline Karyouti & 104 & 14.5 & 80 & 51 \\
\hline Mwaniki et al. & 317 & 30.0 & 50 & 260 \\
\hline
\end{tabular}

Nigeria (Adekeye, 1980; Abiose), Libya (Kalil \& Shaladi, 1981), Europe (Van Hoof et al.; Afzclius \& Rosen, 1980) and USA (Hagan \& Huelke, 1961). Studies in the last two decades have shown that assaults are now the most common cause of maxillofacial fractures in many developed countries (UK (Winstanley, 1984; Ellis et al., 1985; Layton et al.), Australia (Allan \& Daly), Bulgaria (Bakardjiev \& Pechalova), USA (King et al., 2004)). Nevertheless, RTAs 
Table III. Number of fracture locations in the mandible, body, parasymphysis (including symphysis), condyle and angle.

\begin{tabular}{|c|c|c|c|c|c|}
\hline Author & $\begin{array}{c}\text { Mandible ( } \mathbf{N}^{\circ} \text { of } \\
\text { Fractures) }\end{array}$ & $\begin{array}{c}\text { Body } \\
\left(N^{o} \text { of Fractures) }\right.\end{array}$ & $\begin{array}{l}\text { Parasymphyseal } \\
\text { (No of Fractures) }\end{array}$ & $\begin{array}{c}\text { Condyle } \\
\text { ( } \mathbf{N}^{\circ} \text { of } \\
\text { Fractures) }\end{array}$ & $\begin{array}{l}\text { Angle }\left(N^{\circ} \text { of }\right. \\
\text { Fractures) }\end{array}$ \\
\hline Bakardjiev et al. & $\#$ & $\#$ & $\#$ & \# & $\#$ \\
\hline Al-Khateeb et al. & 270 & 107 & 42 & 33 & 47 \\
\hline Deogratius et al. & $\#$ & \# & \# & \# & \# \\
\hline Brasi leiro et al. & 618 & 133 & 139 & 162 & 113 \\
\hline Kadkhodaie & 3089 & 942 & 666 & 790 & 506 \\
\hline Cheema \& Amin & $\#$ & \# & \# & \# & \# \\
\hline Erol et al. & \# & \# & \# & \# & \# \\
\hline Adebayo et al. & \# & \# & $\#$ & \# & \# \\
\hline Motamedi & 173 & 22 & 51 & 55 & 35 \\
\hline Subhashraj et al. & 512 & 42 & 156 & 96 & 60 \\
\hline Al Ahmed et al. & 150 & 30 & 27 & 38 & 35 \\
\hline Ansari & 1633 & 364 & 277 & 325 & 218 \\
\hline Olasoji et al. & 273 & 155 & 75 & 31 & 12 \\
\hline van B eek et al. & 1324 & 509 & 0 & 610 & 180 \\
\hline van B eek et al. & 1187 & 459 & 0 & 532 & 163 \\
\hline Ugboko et al. & 358 & 151 & 40 & 44 & 31 \\
\hline Bataineh & 584 & 134 & 17 & 59 & 104 \\
\hline Oji & 730 & 264 & 112 & 190 & 127 \\
\hline Fasola et al. (2003b) & $\#$ & $\#$ & $\#$ & $\#$ & $\#$ \\
\hline Fasola et al. (2003b) & \# & \# & $\#$ & \# & $\#$ \\
\hline Aksoy et al.. & 507 & 51 & 294 & 42 & 75 \\
\hline Iida et al. & 1508 & 356 & 252 & 507 & 327 \\
\hline Klenk et al. & 150 & 18 & 46 & 44 & 28 \\
\hline Sakr et al. & 792 & 157 & 221 & 142 & 164 \\
\hline Ortako_lu et al. & 161 & 49 & 30 & 42 & 25 \\
\hline King et al. & 225 & 46 & 79 & 27 & 34 \\
\hline Atanasov & 3326 & 857 & 651 & 399 & 1136 \\
\hline Dongas & $\#$ & $\#$ & $\#$ & $\#$ & $\#$ \\
\hline Schön et al. & 154 & 40 & 25 & 14 & 66 \\
\hline Mohammadi et al. & 87 & 17 & 13 & 13 & 24 \\
\hline Allan et al. & $\#$ & $\#$ & $\#$ & $\#$ & $\#$ \\
\hline Khan & 272 & 134 & 12 & 13 & 99 \\
\hline Layton et al. & $\#$ & $\#$ & $\#$ & \# & \# \\
\hline Dimitroulis et al. & $\#$ & $\#$ & $\#$ & \# & \# \\
\hline Perkins et al. & $\#$ & $\#$ & \# & \# & $\#$ \\
\hline Telfer et al. & $\#$ & $\#$ & $\#$ & $\#$ & $\#$ \\
\hline Adi et al. & 632 & 166 & 121 & 165 & 123 \\
\hline Vetter etal. & 290 & 35 & 96 & 73 & 84 \\
\hline Ashar etal. & 185 & 15 & 41 & 59 & 22 \\
\hline Sawhney et al. & 123 & 25 & 41 & 27 & 30 \\
\hline Guven & 102 & 32 & 18 & 7 & 18 \\
\hline Guven & 113 & 26 & 17 & 9 & 19 \\
\hline Sugiura et al. & $\#$ & $\#$ & $\#$ & $\#$ & $\#$ \\
\hline Karyouti & $\#$ & \# & $\#$ & $\#$ & $\#$ \\
\hline Mwaniki et al. & \# & $\#$ & \# & \# & \# \\
\hline
\end{tabular}

\#: Not mentioned in the study.

remain the most frequent cause of injury in many developing areas (Jordan (Bataineh; Ma'aita), Egypt (Sakr et al., 2006), Iran (Ansari) and Pakistan (Cheema \& Amin, 2006)).
As mentioned earlier, the mandible was the most common bone affected by fractures of the facial skeleton. In studies that have reported RTA related facial fractures, 
The body of the mandible was the most common mandibular fracture site (Ugboko et al., 1998; Adebayo et al.; Kadkhodaie; Al-Khateeb \& Abdullah). In contrast, patients with mandibular fractures caused by alleged assault in Scotland had body fractures accounted for 33\% followed by the angle of the mandible (31\%) (Ellis et al.) (Table III).

From the above mentioned literature, there were only few studies from different institutions that compared the pattern of maxillofacial fractures over time (Layton et al.; van Beek \& Merkx; Olasoji et al.). The present comparison was undertaken to examine the trends in the pattern of maxillofacial fractures between developed and developing countries over two time periods; (1987-1999) and (2000-2007).

\section{MATERIAL AND METHOD}

Literature Search and Data Collection. A comprehensive computerized search of the literature was performed (PubMed-National Library of Medicine, NCBI). Key words applied in the search were epidemiology, maxillofacial, fractures and mandibular. Only papers written in English were included as translation for other languages was not available. Search included articles on maxillofacial and mandibular injuries published during the last 20 years, from January 1st/1987 to March 1st/2008, to obtain relatively recent, applied and sufficient data. The abstracts and full-texts of all these articles were thoroughly examined. References were manually searched in these articles to look for additional relevant non-PubMed articles or abstracts. Personal contacts were also made with institutions and investigators of previous studies for missing data and also for the provision of articles found suitable for the review.

A total of 134 full-text articles and abstracts were identified. A total of 45 studies were included in this review; 39 studies dealt with patients who sustained maxillofacial fractures and the remainder 6 articles dealt with patients who had mandibular fractures alone (Tables I \& IV). These 45 articles were included according to the following criteria:

- Availability of the full-text article; in order to obtain all or most of the characteristics of facial fractures.

- Retrospective or prospective studies dealing with all age groups (children and adults) and civilian-type injuries.

- Studies where the diagnoses of fractures were made on the basis of presenting complaints, clinical examination, and were confirmed radiographically, especially orthopantomographic radiographs, and by the findings at operation.

- Studies where fractures were received and managed in maxillofacial units related to hospitals or emergency units or tertiary of primary units.
Five categories with a total of 89 articles were excluded:

- Studies dealing with a certain age group (21 studies) or a single specific aetiology (24 studies) or a certain site of facial fractures (4 studies).

- Studies dealing with patients with solitary head injuries (2 studies) or solitary fractures of the alveolar process or pure dental injuries, possibly in combination with other injuries (3 studies).

- Studies dealing with patients with severe or serious facial fractures (4 studies).

- Studies dealing with complications (10 studies) or treatments (11 studies) of facial fractures.

- Studies where fractures were received and diagnosed in surgical or in Ear, Nose and Throat (ENT) units.

- Unavailability of the full-text article (10 articles).

For each of the included 45 studies, multiple parameters were recorded (Tables I-III). A data collection form was designed and used for the collection of data (Table appendice).

For example, country of treatment was classified into developed and developing. According to the United Nations definition, the term developed country, or advanced country, is used to categorize countries with developed economies in which the tertiary and quaternary sectors of industry dominate. In contrast, a developing country is that country which has relatively low standard of living, an undeveloped industrial base, and a moderate to low Human Development Index (HDI) score and per capita income, but is in a phase of economic development. Usually all countries which are neither a developed country nor a failed state are classified as developing countries. Twenty-six studies were conducted in developing countries and 19 in developed countries.

Furthermore, year of publication ranged from 1987 to 2007, were considered. This period was divided into two periods; period 1 (1987-1999) and period 2 (2000-2007), as this would permit a comparison of the "state of facial injuries" in recent years to ten-to-twenty year old articles around the world.

Due to the heterogeneity of the study methodologies in this review, it was not possible to apply the traditional methods of a systematic review. A meta-analysis is only suitable if there is sufficient similarity in the populations studied and the measurements used. This was not the case with the studies identified in this review. Therefore, calculated "weighed" percentages of each parameter across the total number of all patients were performed. 
Statistical Analysis. Data analysis was undertaken using SPSS version 16 (SPSS Inc., Chicago, IL, USA) statistical software program, including frequency distribution and cross-tabulation. The Chi-Square test was selected to assess the significance of differences in the calculated "weighed" percentages between developed and developing countries over the two periods of treatment. P-value of $<0.05$ was accepted as significant.

\section{RESULTS}

Incidence. In maxillofacial fracture, mandibular fractures were more common than zygomatic and middle third injuries. This study dealed with 37871 patients who sustained maxillofacial injuries in the period 1987-2007 (Table IV). Mandibular fractures were recorded in 21769 patients (57\%) (Table I).

Age and Sex distribution. In the period 1987-2007, the mean age of patients with facial fractures in different countries of the world was 24.4 years. The mean age of the patients in developed and developing countries over the two periods are presented in Table V. The mean age of patients in developed and developing countries in the period 20002007, in comparison to the period 1987-1999, decreased specially in developing countries. The mean age of all patients in the first period was 26.9 years and in the second period 23.3 years. The mean age of all patients in developed countries was 25.8 years and in developing countries 23.3 years.

In the period 1987-2007, the incidence of facial fractures in different countries of the world was higher in males $(81.3 \%)$ than in females. The male to female ratio of patients with facial fractures in developed and developing countries in the period 1987-2007 are presented in Table VI. The male to female ratio of patients with facial fractures recorded in the period 1987-2007 was greater in developing countries (5.1:1.0) than that in developed countries $(3.7: 1.0)$.
Aetiology. RTA was the major cause of facial injuries in developing countries (65.8\%). However, assault was the major cause in developed countries (40.2\%) (Table VII). The percentage of patients with facial fractures due to RTA in the period 1991-2004, in comparison to the period 19871999 , had significantly $(\mathrm{p}<0.005)$ decreased in developed countries and increased in developing countries. In contrast, the percentage of patients with assault-related facial fractures in the period 2000-2007, in comparison to the period 1987-1999, had significantly $(\mathrm{p}<0.005)$ increased in developed countries and decreased in developing countries (Tables VIII and IX).

The most common site of fractured mandible. Of the 19528 fractures that occurred in 15509 patients with mandibular fractures over the period 1987-2007 (Table X), $27.2 \%$ were located in the body, being the most common site followed by the condylar process $(23.2 \%)$, the angle (19.9\%) and parasymphysis (including symphysis) (18.2\%). Only $11.1 \%$ were located in the ramus and coronoid regions, being the least common sites of mandibular fractures.

The body of the mandible was the most common fracture site in developing countries $(26.7 \%)$, where the major aetiology of facial fractures was road traffic accident. It was also the most common fracture site in developed countries $(27.9 \%)$, where the major aetiology was assault. However, the second most common fracture site was parasymphysis (including symphysis) in developing countries (21.4\%) and condylar process in developed countries (26.7\%) (Table X).

The fracture location in the mandible in different types of units, emergency, hospital and tertiary, over the period 1987-2007 are presented in Table XI. For example, of the 7623 mandibular fractures received in emergency units over the period 1987-2007, 30.9\% were diagnosed in the condyle, being the most common site followed by the body (28.8\%), the angle (16.2\%) and parasymphysis (including symphysis) (13.1\%). Only $11.8 \%$ were located in the ramus and coronoid regions, being the least common sites of mandibular fractures diagnosed in emergency units.

Table IV. Division of patients of the included studies according to localization of facial fractures.

\begin{tabular}{lccr}
\hline Localization & Number of Studies & Number of Patients & $\%$ \\
\hline Maxillofacial fractures & 39 & 37871 & 89 \\
Mandibular fractures & 6 & 4663 & 11 \\
Total & 45 & 42534 & 100 \\
\hline
\end{tabular}


Table V. The mean age of patients in developed and developing countries over periods 1987-1999, 2000-2007 and 1987-2007.

\begin{tabular}{llccc}
\hline & \multicolumn{4}{c}{ Period of Treatment } \\
Country of & Developed & 26.8 & 24.4 & 25.8 \\
\cline { 3 - 5 } Study & Developing & 27.4 & 22.6 & 23.3 \\
& Both & 26.9 & 23.3 & 24.4 \\
\hline
\end{tabular}

Table VI. The male to female ratio of patients with facial fractures in developed and developing countries over the period 1987-2007.

\begin{tabular}{|c|c|c|}
\hline & & Period of Treatment \\
\hline \multirow{5}{*}{$\begin{array}{l}\text { Country of } \\
\text { Study }\end{array}$} & \multirow[b]{2}{*}{ Developed } & $1987-2007$ \\
\hline & & $\begin{array}{l}\text { Male: } 15074(78.6 \%) \\
\text { Female: } 4097(21.4 \%) \\
\text { Male: Female } \quad 3.7: 1\end{array}$ \\
\hline & Developing & $\begin{array}{l}\text { Male: } 19547(83.6 \%) \\
\text { Female: } 3813(16.4 \%) \\
\text { Male: Female } 5.1: 1\end{array}$ \\
\hline & \multirow[t]{2}{*}{ Both } & $\begin{array}{c}\text { Male: } 34621(81.3 \%) \\
\text { Female: } 7910(18.7 \%)\end{array}$ \\
\hline & & Male: Female $\quad 4.4: 1$ \\
\hline
\end{tabular}

Table VII. Main aetiological factors of facial fractures in developed and developing countries.

\begin{tabular}{llcccc}
\hline & & \multicolumn{3}{c}{ Country of the Study } \\
\cline { 3 - 6 } & $\begin{array}{c}\text { Developing } \\
\mathbf{N}^{\circ} \text { of Patients }\end{array}$ & $(\%)$ & $\begin{array}{c}\text { Developed } \\
\mathrm{N}^{\circ} \text { of Patients }\end{array}$ & $(\%)$ \\
\hline $\begin{array}{l}\text { Aetiology of } \\
\text { Fracture }\end{array}$ & $\begin{array}{l}\text { Road Traffic } \\
\text { Accidents }\end{array}$ & 15389 & 65.8 & 5774 & 30.1 \\
& Assault & 2501 & 10.7 & 7720 & 40.2 \\
& All Other Causes & 5470 & 23.5 & 5680 & 29.7 \\
\hline Total & & 23360 & 100 & 19174 & 100 \\
\hline
\end{tabular}

Table VIII. Main aetiological factors of facial fractures over periods 1987-1999 and 2000-2007 in developed countries.

\begin{tabular}{|c|c|c|c|c|c|}
\hline & & \multicolumn{4}{|c|}{ Period of Treatment } \\
\hline & & \multicolumn{2}{|c|}{$1987-1999$} & \multicolumn{2}{|c|}{$2000-2007$} \\
\hline & & $\mathrm{N}^{\circ}$ of Patients & $\%$ & $\mathrm{~N}^{\mathrm{o}}$ of Patients & $\%$ \\
\hline \multirow{3}{*}{$\begin{array}{l}\text { Developed } \\
\text { Countries }\end{array}$} & Assault & 3774 & 33.8 & 3946 & 49.1 \\
\hline & Road traffic accident & 3564 & 31.9 & 2210 & 27.5 \\
\hline & All Other Causes & 3804 & 34.1 & 1876 & 23.3 \\
\hline \multicolumn{2}{|l|}{ Total } & 11142 & 100 & 8032 & 100 \\
\hline
\end{tabular}


Table IX. Main aetiological factors of facial fractures over periods 1987-1999 and 2000-2007 in developing countries

\begin{tabular}{llcccc}
\hline & & \multicolumn{4}{c}{ Period of Treatment } \\
\cline { 3 - 6 } & & \multicolumn{2}{c}{$1987-1999$} & \multicolumn{2}{c}{$2000-2007$} \\
& & $\mathrm{~N}^{\circ}$ of Patients & $\%$ & $\mathrm{~N}^{\circ}$ of Patients & $\%$ \\
\hline Developing & Assault & 752 & 41.7 & 1776 & 8.2 \\
& Rountries & 756 & 41.9 & 14633 & 67.8 \\
& All Other Causes & 294 & 16.3 & 5149 & 23.8 \\
\hline Total & & 1802 & 100 & 21558 & 100 \\
\hline
\end{tabular}

Table X. Number $(\%)$ of fracture location in the mandible in developed and developing countries over the period 1987-2007.

\begin{tabular}{lccc}
\hline Localization & Developing & Developed & Both \\
\hline Body & $2718(26.7 \%)$ & $2618(27.9 \%)$ & $5336(27.2 \%)$ \\
Parasymphyseal and symphyseal & $2183(21.4 \%)$ & $1376(14.7 \%)$ & $3559(18.2 \%)$ \\
Condyle & $2046(20.1 \%)$ & $2502(26.7 \%)$ & $4548(23.2 \%)$ \\
Angle & $1655(16.2 \%)$ & $2250(24.0 \%)$ & $3905(19.9 \%)$ \\
Ramus and Coronoid & $1575(15.4 \%)$ & $605(6.4 \%)$ & $2180(11.1 \%)$ \\
\hline Total & $10177(100 \%)$ & $9351(100 \%)$ & $19528(100 \%)$ \\
\hline
\end{tabular}

Table XI. Number (\%) of fracture location in the mandible in different units over the period 1987-2007.

\begin{tabular}{lcccc}
\hline Localization & Emergency & Hospital & Tertiary & Total \\
\hline Body & $2199(28.8 \%)$ & $2475(25.6 \%)$ & $662(29.6 \%)$ & $5336(27.2 \%)$ \\
Parasymphyseal & $1003(13.1 \%)$ & $2108(21.8 \%)$ & $448(20 \%)$ & $3559(18.2 \%)$ \\
Condyle & $2358(30.9 \%)$ & $1691(17.5 \%)$ & $499(22.3 \%)$ & $4548(23.2 \%)$ \\
Angle & $1237(16.2 \%)$ & $2269(23.5 \%)$ & $399(17.9 \%)$ & $3905(19.9 \%)$ \\
Ramus & $896(11.8 \%)$ & $1127(11.7 \%)$ & $227(10.2 \%)$ & $2180(11.1 \%)$ \\
\hline Total & $7623(100 \%)$ & $9670(100 \%)$ & $2235(100 \%)$ & $19528(100 \%)$ \\
\hline
\end{tabular}

\section{DISCUSSION}

The result of the present study revealed that the incidence and aetiology of maxillofacial fractures vary widely between different countries as a result of various contributing factors, such as age, gender, environment and the socioeconomic status and culture of the patient (Kruger et al.).

Most facial bone fractures involve the mandible and this might be related to the direction and quantity of force that the mandible is exposed to ( $\mathrm{Al}$ Ahmed et al.). The mobility of the mandible and the fact that it has less bony support than the maxilla had been implicated (Kelly \& Harrigan, 1975).
In this study, most patients affected by facial fractures were young adult males with a mean age of 24.4 years. A tendency towards an equal mean age was observed between earlier and later studies across the world. The possible explanation for this is that individuals between the ages of 21 and 30 years frequently take part in dangerous exercises and sports, drive motor vehicles carelessly, and are more likely to be involved in violence (Oji). In men, the third decade of life is an active period when they are more energetic, involved in high-speed transportation, and engaged in outdoor activities, which are leading causes of maxillofacial trauma (Cheema \& Amin). 
This study showed that the incidence of facial fractures in different countries of the world was higher in males $(81.3 \%)$ than in females. The male-to-female ratio of patients with facial fractures was greater in developing countries than that in developed countries (Table VI). This can be attributed to the high percentage of women who are used to stay at home, not work in outdoor and high-risk occupations in developing countries, thus becoming less exposed to RTA and other causes of maxillofacial injuries (Fasola et al., 2003b; Al Ahmed et $a l$.). These results were in agreement with those achieved in developing countries (Al-Balbissi, 2003; Al Ahmed et al.; Ghaffar et al., 2004; Roudsari et al., 2004; Hofman et al., 2005).

In contrast, in developed countries where women participate directly in social activities and consequently are more susceptible to traffic accidents and urban violence (Lindqvist et al.; Thorn et al.; Gassner et al., 1999), the maleto-female ratio incurring maxillofacial injuries reached as low as 2.1:1.0 (Gassner et al.). Women's facial injury rates in developed countries are more than that in developing countries, showing that certain socioeconomic conditions are necessary for women to play a more active part in these developed societies (Lindqvist et al.; Thorn et al.; Peden et al., 2005; Kruger et al.).

In this study, RTA was the major cause of facial injuries in developing countries $(65.8 \%)$. The percentage of patients with facial fractures due to RTA in the period 20002007 , in comparison to the period 1987-1999, had significantly $(\mathrm{p}<0.005)$ decreased in developed countries and increased in developing countries. These findings are in agreement with reports from other developing countries where RTA remains the major aetiologic factor of maxillofacial injuries (Fasola $e t$ al., 2003a; Al Ahmed et al.; Ansari; Nwoku \& Oluyadi, 2004).

Facial fractures related to RTA are explained by the increase of vehicles, insufficient stress on the use of seat belts, recklessness on the highways, badly maintained roads, and lack of enforcement of traffic rules and regulations (Kalil \& Shaladi; Hill et al., 1984; Ugboko et al.; Fasola et al., 2003b; Kobusingye , 2004). In 1995, The World Health Organisation (WHO) has estimated that nearly $25 \%$ of all injury fatalities worldwide are a result of road traffic crashes, with $90 \%$ of the fatalities occurring in developing countries (Kobusingye). Therefore, there is an urgent need to get down to what the developed nations have done to reduce and/or prevent road traffic crashes.

In this study, assault was the major cause of facial fractures in developed countries $(40.2 \%)$. The percentage of patients with assault-related facial fractures in the period 20002007 , in comparison to the period 1987-1999, had significantly $(p<0.005)$ increased in developed countries and decreased in developing countries. These findings are in agreement with reports from developed countries where assaults and interpersonal violence have replaced RTA as the major cause of maxillofacial injuries (McDade et al., 1982; Andersson et al., 1984; Shepherd et al., 1988; Magennis et al., 1998; Fasola et al., 2003b; King et al.; Laski et al.).

In Scandinavian countries, alcohol or narcotic involvement in facial fractures had been reported between 44 $\%$ to $56 \%$, and most of the cases associated with violence were linked to alcohol abuse (Heimdahl \& Nordenram, 1977; Oikarinen et al., 1992). In contrast, alcohol does not play a major role for facial fracture aetiology in the Middle East where it is forbidden in some countries (Saudi Arabia, Iran and Libya) and consumed minimally in the other countries due to religious and cultural beliefs.

Regarding the fracture site of the mandible, the body was the most common fracture site in developing countries (26.7\%) where the major aetiology of facial fractures was road traffic accident as revealed by this study. It was also the most common fracture site in developed countries $(27.9 \%)$ where the major aetiology was assault. The prevalence of fractures of the mandibular body also confirmed the previous reports by Adekeye and Abiose in Nigeria and Khalil \& Shaladi in Libya. However, most reports from Europe and North America showed the condyle as the most common site of mandibular fracture (Beck, 1989). This might indicate that there is no clear association between the aetiological factors and the fracture site of the mandible (Ellis et al.; Vetter et al.; Ugboko et al.; Adebayo et al.; Brasileiro \& Passeri; Kadkhodaie).

In this study, mandibular body fractures were the most fracture location diagnosed in hospitals and tertiary units, while condylar fractures were the most fracture location diagnosed in emergency units. This might be attributed to the common use of orthopantomograph for the diagnosis of mandibular fractures, especially in the condylar region, in emergency units more than other units.

Finally, civilization, culture, and individual characteristics are major factors that determine trends of maxillofacial trauma. Public awareness of traffic regulations and alcohol intake, and good quality of socioeconomic status might affect the trends of these types of trauma.

\section{CONCLUSIONS}

Within the limits of the included maxillofacial literature that dealt with the incidence, aetiology, sex, and age, it was concluded that mandibular fractures are more common than middle third injuries of the facial skeleton. 
Most patients affected by facial fractures were young adult males. The male-to-female ratio of patients with facial fractures was greater in developing countries than that in developed countries. Assault was the most common aetiology in developed- compared to developing countries, where RTA was the major aetiology.

SHAYYAB, M.; ALSOLEIHAT, F.; RYALAT, S. \& KHRAISAT, A. Tendencias en el patrón de fracturas faciales en diferentes países del mundo. Int. J. Morphol., 30(2):745-756, 2012.

RESUMEN: El objetivo del estudio fue examinar los cambios en el patrón de las fracturas maxilofaciales entre los países desarrollados y en vías de desarrollo en dos períodos de tiempo (1987-1999) y (2000-2007). Una búsqueda exhaustiva de la literatura en PubMed se llevó a cabo entre las publicaciones de lesiones maxilofaciales publicados durante los últimos 20 años. Sólo 45 artículos cumplieron con los criterios de inclusión, y los textos completos de estos artículos fueron examinados a fondo. En cada uno de los estudios incluidos se registraron diferentes parámetros. Se calculó el porcentaje de "peso" de cada parámetro a través del número total de pacientes. La mandíbula fue el hueso facial más fracturado (57\%). En todo el periodo evaluado, la media de edad de los pacientes con fracturas faciales fue de 24,4 años y la incidencia de las fracturas faciales fue mayor en hombres $(81,3 \%)$ que en mujeres. La razón hombre-mujer de los pacientes con fracturas faciales fue mayor en los países en vías de desarrollo $(5,1: 1,0)$ que en los países desarrollados $(3,7: 1,0)$ en todo el período. Las lesiones relacionadas con accidentes de tránsito disminuyeron considerablemente en los países desarrollados, mientras que aumentó en los países en vías de desarrollo durante los dos períodos. Sin embargo, las lesiones faciales relacionadas con asaltos aumentaron considerablemente en los países desarrollados y disminuyó en los países en vías de desarrollo durante los dos períodos. El cuerpo de la mandíbula fue el sitio de fractura más común (27,2\%). Se concluyó que las fracturas mandibulares son las lesiones más comunes en el tercio medio del esqueleto facial. La mayoría de los pacientes afectados por fracturas faciales en los diferentes países fueron hombres jóvenes.

PALABRAS CLAVE: Epidemiología; Fractura maxilofacial; Fractura mandibular; Accidente de tránsito.

\section{REFERENCES}

Abiose, B. O. Maxillofacial injuries in the western states of Nigeria. Br. J. Oral Maxillofac. Surg., 24(1):31-9, 1986.

Adebayo, E. T.; Ajike, O. S. \& Adekeye, E. O. Analysis of the pattern of maxillofacial fractures in Kaduna, Nigeria. Br. J. Oral Maxillofac. Surg., 41(6):396-400, 2003.

Adekeye, E. O. Fractures of the zygomatic complex in Nigerian patients. J. Oral Surg., 13(8):596-9, 1980.

Adi, M.; Ogden, G. R. \& Chisholm, D. M. An analysis of mandibular fractures in Dundee Scotland (1977 to 1985). Br. J. Oral Maxillofac. Surg., 28(3):194-9, 1990.

Afzelius, L. E. \& Rosén, C. Facial fractures. A review of 368 cases. Int. J. Oral Surg., 9(1):25-32, 1980.

Al Ahmed, H. E.; Jaber, M. A.; Abu Fanas, S. H. \& Karas, M. The pattern of maxillofacial fractures in Sharjah, United Arab Emirates: a review of 230 cases. Oral Surg. Oral Med. Oral Pathol. Oral Radiol. Endod., 98(2):166-70, 2004.

Al-Balbissi, A. H. Role of gender in road accidents. Traffic Inj. Prev., 4(1):64-73, 2003.

Al-Khateeb, T. \& Abdullah, F. M. Craniomaxillofacial injuries in the United Arab Emirates: a retrospective study. J. Oral Maxillofac. Surg., 65(6):1094-101, 2007.

Allan, B. P. \& Daly, C. G. Fractures of the mandible; a 35-year retrospective study. Int. J. Oral Maxillofac. Surg., 19(5):268$71,1990$.

Andersson, L.; Hultin, M.; Nordenram, A. \& Ramstrom, G. Jaw fractures in the county of Stockholm (1978-1980)(I) general survey. Int. J. Oral Surg., 13(3):194-9, 1984.

Ansari, M. H. Maxillofacial fractures in Hamedan province, Iran: a retrospective study (1987-2001). J. Craniomaxillofac. Surg., 32(1):28-34, 2004.

Bakardjiev, A. \& Pechalova, P. Maxillofacial fractures in Southern Bulgaria - a retrospective study of 1706 cases. J. Craniomaxillofac. Surg., 35(3):147-50, 2007.

Bataineh, A. B. Aetiology and incidence of mandibular fractures in the north of Jordan. Oral Surg. Oral Pathol. Oral Med. Oral Radiol. Endod., 86:31-5, 1998.

Beck, R. A. \& Blakeslee, D. B. The changing picture of facial fracture: 5 years review. Arch. Otolaryngol. Head Neck Surg., 115(7):826-9, 1989.

Bochlogyros, R. N. A retrospective study of 1,521 mandibular fractures. J. Oral Maxillofac. Surg., 43(8):597-9, 1998.

Brasileiro, B. F. \& Passeri, L. A. Epidemiological analysis of maxillofacial fractures in Brazil: a 5-year prospective study. Oral Surg. Oral Med. Oral Pathol. Oral Radiol. Endod., 102(1):28-34, 2006. 
Brook, I. M. \& Wood, N. Aetiology and incidence of facial fractures in adults. Int. J. Oral Surg., 12(5):293-8, 1983.

Chambers, I. G. \& Scully, C. Mandibular fractures in India during the Second World War; analysis of the Snawdon series. Br. J. Oral Maxillofac. Surg., 25(5):357-69, 1987.

Cheema, S. A. \& Amin, F. Incidence and causes of maxillofacial skeletal injuries at the Mayo Hospital in Lahore, Pakistan. Br. J. Oral Maxillofac. Surg., 44(3):232-4, 2006.

Ellis, E. 3rd.; Moos, K. F. \& el-Attar, A. Ten years of mandibular fractures: An analysis of 2137 cases. Oral Surg. Oral Med. Oral Pathol., 59(2):120-9, 1985.

Erol, B.; Tanrikulu, R. \& Görgün, B. Maxillofacial fractures. Analysis of demographic distribution and treatment in 2901 patients (25-year experience). J. Craniomaxillofac. Surg., 32(5):308-13, 2004.

Fasola, A. O.; Lawoyin, J. O.; Obiechina, A. E. \& Arotiba, J. T. Inner city maxillofacial fractures due to road traffic accidents. Dent. Traumatol., 19(1):2-5, 2003a.

Fasola, A. O.; Nyako, E. A.; Obiechina, A. E. \& Arotiba, J. T. Trends in the Characteristics of Maxillofacial Fractures in Nigeria. J. Oral. Maxillofac. Surg., 61(10):1140$3,2003 b$.

Gassner, R.; Tuli, T.; Emshoff, R. \& Waldhart, E. Mountainbiking - a dangerous sport: comparison with bicycling on oral and maxillofacial trauma. Int. J. Oral Maxillofac. Surg., 28(3):188-91, 1999.

Ghaffar, A.; Hyder, A. A. \& Masud, T. I. The burden of road traffic injuries in developing countries: the 1 st national injury survey of Pakistan. Public Health, 118(3):211-7, 2004.

Guven, O. A Comparative Study on Maxillofacial Fractures in Central and Eastern Anatolia. J. Craniomaxillofac. Surg., 16(3):126-9, 1988.

Hagan, E. H. \& Huelke, D. F. An analysis of 319 case reports of mandibular fractures. J. Oral Surg. Anaesth. Hosp. Dent. Serv., 19:93-104, 1961.

Heimdahl, A. \& Nordenram, A. The first 100 patients with jaw fractures at the Department of Oral Surgery, Dental School, Huddinge. Swed. Dent. J., 1(5):177-8, 1977.

Hill, C. M.; Crosher, R. F.; Carrol, M. J. \& Mason, D. A. Facial fractures-the results of 4-year prospective study. $J$. Maxillofac. Surg., 12:267-70, 1984.

Hill, C. M.; Burford, A.; Martin, A. \& Thomas, D. W. A one-year review of maxillofacial sports injuries treated at an accident and emergency department. Br. J. Oral Maxillofac. Surg., 36(1):44-7, 1998.
Hofman, K.; Primack, A.; Keusch, G. \& Hrynkow, S. Addressing the growing burden of trauma and injury in low-and middleincome countries. Am. J. Public Health, 95(1):13-7, 2005.

Iida, S.; Kogo, M.; Sugiura, T.; Mima, T. \& Matsuya, T. Retrospective analysis of 1502 patients with facial fractures. Int. J. Oral Maxillofac. Surg., 30(4):286-90, 2001.

Kadkhodaie, M. H. Three-year review of facial fractures at a teaching hospital in northern Iran. Br. J. Oral Maxillofac. Surg., 44(3):229-31, 2006.

Kalil, A. F. \& Shaladi, O. A. Fractures of the facial bone in the eastern region of Libya. Br. J. Oral Surg., 19(4):300-4, 1981.

Karyouti, S. K. Maxillofacial injuries at Jordan University Hospital. Int. J. Oral Maxillofac. Surg., 16(3):262-5, 1987.

Kelly, D. E. \& Harrigan, W. F. A Survey of facial fractures: Bellevue Hospital, 1948-1974. J. Oral Surg., 33(2):146-9, 1975.

King, R. E.; Scianna, J. M. \& Petruzzelli, G. J. Mandible fracture patterns: a suburban trauma center experience. Am. J. Otolaryngol., 25(5):301-7, 2004.

Kobusingye, O. C. Why poor countries cannot afford to ignore road safety. Afr. J. Trauma, 2:6, 2004.

Kruger, E.; Smith, K. \& Tennant, M. Tennant: Jaw fractures in the indigenous and nonindigenous populations of Western Australia: 1999-2003. Int. J. Oral Maxillofac. Surg., 35(7):65862,2006

Kummoona, R. \& Muna, A. M. Evaluation of immediate phase of management of missile injuries affecting maxillofacial region in Iraq. J. Craniofac. Surg., 17(2):217-23, 2006.

Laski, R.; Ziccardi, V. B.; Broder, H. L. \& Janal, M. Facial trauma: a recurrent disease? The potential role of disease prevention. J. Oral Maxillofac. Surg., 62(6):685-8, 2004.

Layton, S.; Dickenson, A. J. \& Norris, S. Maxillofacial fractures: a study of recurrent victims. Injury, 25(8):523-5, 1994.

Le, B. T.; Dierks, E. J.; Ueeck, B. A.; Homer, L. D. \& Potter, B. F. Maxillofacial injuries associated with domestic violence. $J$. Oral Maxillofac. Surg., 59(11):1277-84, 2001.

Lindqvist, C.; Sorsa, S.; Hyrkäs, T. \& Santavttra, S. Maxillofacial fractures sustained in bicycle accidents. Int. J. Oral Maxillofac. Surg., 15(1):12-8, 1986.

Ma'aita, J. K. Analysis of maxillofacial fractures in Jordan. Saudi Med. J., 20:461-4, 1999.

Magennis, P.; Shepherd, J.; Hutchison, I. \& Brown, A. Trends in facial injuries: increasing violence more than compensate for decreasing road trauma. Br. Med. J., 316:325-33, 1998. 
McDade, A. M.; McNicol, R. D.; Ward-Booth, P.; Chesworth, J. \& Moos, K. F. The aetiology of maxillofacial injuries, with special reference to the abuse of alcohol. Int. J. Oral Surg., 11(3):152-5, 1982.

Motamedi, M. H. An assessment of maxillofacial fractures: a 5year study of 237 patients. J. Oral Maxillofac. Surg., 61(1):614, 2003.

Mwaniki, D. L. \& Guthua, S. W. Occurrence and characteristics of mandibular fractures in Nairobi, Kenya. Br. J. Oral Maxillofac. Surg., 28(3):200-2, 1990.

Nwoku, A. L. \& Oluyadi, B. A. Retrospective analysis of 1206 maxillofacial fractures in an urban Saudi hospital: 8 year review. Pakistan Oral Dent. J., 24:13-6, 2004.

Oikarinen, K.; Silvennoinen, U. \& Ignatius, E. Frequency of alcohol associated mandibular fractures in northern Finland in the 1980s. Alcohol Alcohol., 27(2):189-93, 1992.

Oji, C. Jaw fractures in Enugu, Nigeria, 1985-95. Br. J. Oral Maxillofac. Surg., 37(2):106-9, 1999.

Olasoji, H. O.; Tahir, A. \& Arotiba, G. T. Changing picture of facial fractures in northern Nigeria. Br. J. Oral Maxillofac. Surg., 40(2):140-3, 2002.

Peden, M.; Scurfield, R.; Sleet, D.; Mohan, D.; Hyder, A. A.; Jarawan, E.; et al. World report on road traffic injury prevention. Geneva, World Health Organization and World Bank, 2005.

Rix, L.; Stevenson, A. R. L. \& Punnia-Moorthy A. An analysis of 80 -cases of mandibular fractures treated with miniplate osteosynthesis. Int. J. Oral Maxillofac. Surg., 20(6):337-41, 1991.

Roudsari, B. S.; Sharzei, K. \& Zargar, M. Sex and age distribution in transport-related injuries in Tehran. Accid. Anal. Prev., 36(3):391-8, 2004.

Sakr, K.; Farag, I. A. \& Zeitoun, I. M. Review of 509 mandibular fractures treated at the University Hospital, Alexandria, Egypt. Br. J. Oral Maxillofac. Surg., 44(2):107-11, 2006.

Shepherd, J. P.; Gayford, J. J.; Leslie, I. G. \& Scully, C. Female victim of assault: A study of hospital attenders 1988. $J$. Craniomaxillofac. Surg., 16(5):233-7, 1988.

Subhashraj, K.; Nandakumar, N. \& Ravindran, C. Review of maxillofacial injuries in Chennai, India: A study of 2748 cases. Br. J. Oral Maxillofac. Surg., 45(8):637-9, 2007.

Thorn, J. J; Mogeltoft, M. \& Hansen, P. K. Incidence and aetiology pattern of jaw fractures in Greenland. Int. J. Oral Maxillofac. Surg., 15(4):372-9, 1986.
Ugboko, V. I.; Odusanya, S. A. \& Fagade, O. O. Maxillofacial fractures in a semi-urban Nigerian teaching hospital: A review of 442 cases. Int. J. Oral Maxillofac. Surg., 27(4):286-9, 1998.

van Beek, G. J. \& Merkx, C. A. Changes in the pattern of fractures of the maxillofacial skeleton. Int. J. Oral Maxillofac. Surg., 28(6):424-8, 1999.

van Hoof, R. F.; Merkx, C. A. \& Stekelenburg, E. C. The different patterns of fractures of facial skeleton in 4 European countries. Int. J. Oral Surg., 6(1):3-11, 1977.

Vetter, J. D.; Topazian, R. G.; Goldberg, M. H. \& Smith, D. G. Facial fractures occurring in a medium-sized metropolitan area. Recent trends. Int. J. Oral Maxillofac. Surg., 20(4):214-6, 1991.

Winstanley, R. P. The management of fractures of the mandible. Br. J. Oral Maxillofac. Surg., 22(3):170-7, 1984.

Correspondence to:

Dr. Firas Alsoleihat

Faculty of Dentistry

University of Jordan

Amman 11942

JORDAN

Tel: + 962777946631

Email: firas.alsoleihat@ju.edu.jo

Received: 25-09-2011

Accepted: 27-12-2011 